\title{
From the editor of Rediscovered Classics
}

\author{
Peter J. Lambert
}

Received: 20 February 2013 / Accepted: 20 February 2013 / Published online: 15 March 2013

(C) Springer Science+Business Media New York 2013

The Journal of Economic Inequality was founded in 2003 to serve as a vehicle for new ideas and to counter a perceived neglect of distributional issues among many research economists, and now provides the profession with a reliable outlet for serious and innovative research into the many aspects of economic inequality. The articles appearing in $J O E I$ all concern distributional analysis related to economic and social inequalities — not just inequalities in earnings and household incomes, but also in educational opportunities, health and health care, morbidity, and mortality, to name a few - as well as focusing upon the widening gap between rich and poor countries and, of course, always with an eye to policy implications. The Rediscovered Classics series began in 2007, with the function of bringing to the bright light of day some earlier papers on distributional analysis which had remained unpublished, or were hard to access-'lacunae,' if you like, effectively outwith the material substance of our research field.

There have been eleven Rediscovered Classics so far, spanning diverse questions and topics, all with a concern for economic inequality at their core. In date order of their original appearances in books, journals or working papers, here they are:

- benchmark material written in Italian by Corrado Gini in 1912, focusing on the original formulations of the Gini coefficient, and translated by Lidia Ceriani and Paolo Verme [2];

- the fundamental generalized Lorenz dominance theorem, traced back to a 1949 paper in Cyrillic script by Miodrag Tomić [11] (translation);

$\checkmark \quad$ extracts from Serge Kolm's [5] landmark analysis of income inequality which took place between 1963 and 1965;

$\checkmark \quad$ a follow-up paper from 1973, by Tony Atkinson [1], to the beacon, the guiding light of our research area, known to all of us as 'Atkinson 1970';

P. J. Lambert $(\bowtie)$

University of Oregon, Eugene, OR, USA

e-mail: plambert@uoregon.edu 
$\checkmark \checkmark$ three papers from the early 1990s, on distributionally sensitive measures of unemployment, by Manimay Sengupta [7] and Tony Shorrocks [8, 9], which have done much to bridge the traditional gap between labour economics and welfare economics;

$\checkmark \quad$ a 1992 paper on bipolarization and the disappearing middle class, by James Foster and Michael Wolfson [4], whose fundamentals and constructions have now become central;

$\checkmark \quad$ a 1995 paper by Robert Moffitt and Peter Gottschalk [6], on the variability of earnings inequality in the U.S., containing methodology which is now used routinely in other applications;

$\checkmark \quad$ and, most recently, two foundational papers from 1997 and 1999, one by Frédéric Chantreuil and Alain Trannoy [3], the other by Tony Shorrocks [10], on the use of the Shapley rule in distributional analysis.

These signal contributions, which have truly been milestones in our field, all remained relatively inaccessible to the JOEI readership until Rediscovered Classics came along. We need ideas for more Rediscovered Classics! If you have any such ideas, for influential but perhaps forgotten or inaccessible contributions, papers which you would like to see shared with fellow readers of JOEI, please send me an email. Thank you!

\section{References}

1. Atkinson, A.B.: More on the measurement of inequality. J. Econ. Inequal. 6, 277-283 (2008). Preceded by an Editor's Introduction

2. Ceriani, L., Verme, P.: The origins of the Gini index: extracts from Variabilità e Mutabilità (1912) by Corrado Gini. J. Econ. Inequal. 10, 421-443 (2012). Preceded by an Editor's Introduction

3. Chantreuil, F., Trannoy, A.: Inequality decomposition values: the trade-off between marginality and efficiency. J. Econ. Inequal. 11, 83-98 (2013). Preceded by an Editor's Introduction

4. Foster, J.E., Wolfson, M.C.: Polarization and the decline of the middle class. J. Econ. Inequal. 8, 247-273 (2010). Preceded by an Editor's Introduction

5. Kolm, S.-Ch.: The optimal production of social justice: excerpts. J. Econ. Inequal. 5, 216-234 (2007). Preceded by an Editor's Introduction

6. Moffitt, R.A., Gottschalk, P.: Trends in the covariance structure of earnings in the U.S.: 19691987. J. Econ. Inequal. 9, 439-459 (2011). Preceded by an Editor's Introduction, co-written with S.P. Jenkins

7. Sengupta, M.: Unemployment duration and the measurement of unemployment. J. Econ. Inequal. 7, 273-294 (2009). Preceded by an Editor's Introduction

8. Shorrocks, A.F.: Spell incidence, spell duration and the measurement of unemployment. J. Econ. Inequal. 7, 295-310 (2009). Preceded by an Editor's Introduction

9. Shorrocks, A.F.: On the measurement of unemployment. J Econ Inequal. 7, 311-327 (2009). Preceded by an Editor's Introduction

10. Shorrocks, A.F.: Decomposition procedures for distributional analysis: a unified framework based on the Shapley value. J. Econ. Inequal. 11, 99-126 (2013). Preceded by an Editor's Introduction

11. Tomić, M.: Gauss' theorem concerning the center of gravity and its application. J. Econ. Inequal. 8, 123-132 (2010). Preceded by an Editor's Introduction, co-written with I. Urban 